\section{Tarasov V., Rumyantsev V., Mosejko Yu., Potapenkov A.}

\title{
SEARCH FOR THE WAYS TO IMPROVE THE OPERATIONAL RELIABILITY OF THE ROLLING MILLS
}

Об'єктом дослідження є шарнірний вузол універсального шпинделя прокатних станів. Найбільш поширено для таких станів використовуються шарніри з антифрикційними вкладишами з тертям ковзання. Одним з найбільших проблемних місць шарніру з тертям ковзання є нерівномірність розподілу тиску на контактній поверхні сегментів, що знижує зносостійкість вкладишів та експлуатаційну надійність шпинделя. Для виявлення причин нерівномірності тиску і визначення зон значного перевищення крутильних навантажень проводились дослідження на розробленій математичній моделі шарніру.

В ході досліджень використовувався математичний аналіз впливу параметрів вкладишів на величину тиску на контактних поверхнях при робочих навантаженнях лопаті валків і сегментів вкладишів шарніру. Визначено параметри зон підвищеного тиску в контакті вкладишів типової форми у вигляді суцільного сегменту із пласкою і циліндричною поверхнями. Встановлено, що необхідно змінити площину перерізу вкладишу по довжині і ширині сегменту.

Отримано аналітичні залежності параметрів шарніру від діючих навантажень $і$ тиску. Виведено формули визначення геометричних розмірів сегментів шарніру з врахуванням його радіусу $і$ жорсткості. Дослідження шарніру з вкладишами, в яких виконано скоси на пласкій поверхні та ухили до ториів за довжиною і від середини до бокових граней, вказало на можливість рівномірного розподілу тиску за довжиною і шириною сегментів вкладишів.

Таким чином, дослідження на математичній моделі $і$ в лабораторних умовах показало, що доцільним $\epsilon$ використання розробленої конструкиї вкладишу із перемінною площиною перерізу по довжині $і$ ширині вкладишу. Рівномірність розподілу контактних навантажень підтверджена епюрами тиску за довжиною і шириною сегментів. Завдяки цьому забезпечується можливість підвищення зносостійкості шарнірного вузла універсальних шпинделів потужних прокатних станів. В порівнянні з відомими конструкціями шарнірів суттєво підвищується експлуатащійна надійність шпинделів та термін безаварійної роботи станів.

Ключові слова: надійність прокатних станів, універсальний шпиндель, контактний тиск, рівномірність зносу.

\section{Introduction}

One of the bottlenecks of rolling mills is the lack of reliability of universal spindles of the main drive of the mill [1, 2]. The most common design of a spindle hinge is sliding friction hinges. Their lifespan depends on the distribution of pressure on the working surfaces.

Therefore, it is relevant to study the causes of the uneven distribution of pressure in the contact area of the hinge between the liners and the roller blade and to determine areas of significant excess of torsion loads on the liner.

\section{The object of research and its technological audit}

The object of research is the hinge joint of the universal spindle of rolling mills. The solution to the problem of reliability of universal spindles are made in various constructive ways, mainly due to the improvement of the hinge joint. Test hinges: wobbler, with gearing, ball, roller, with Hook's hinge on rolling bearings and with sliding friction with anti-friction liners [3, 4]. Analysis of the capabilities of the wobblers and with gearing of the hinges shows their significant shortcomings:

- complexity and high cost of construction;

- ball and roller hinges with low energy losses due

to friction requiring high manufacturing costs;

- increase in overall dimensions of the hinge.
Dimensions increase even more when using Hooke's hinge with rolling bearings.

In the presence of a high efficiency of the hinge, the following disadvantages are identified also: the dynamic load on the universal spindle increases when the torque is transmitted to the work rolls. This requires an additional increase in the strength of the spindles due to the more expensive steel grades, or an increase in the diameter of the spindle body. In general, the use of the considered structures found a place in low- and medium-grade mills. However, the existing drawbacks of the hinges have delayed their implementation on powerful rolling mills.

Production practice has shown that the most appropriate design for such mills is hinges with anti-friction liners. They are distinguished by small dimensions, low inertia, easy of installation and repair.

One of the most problematic parts of the hinge with sliding friction is the uneven distribution of pressure on the contact surface of the segments, which reduces the wear resistance of liners and operational reliability of the spindle.

\section{The aim and objectives of research}

The aim of research is development of proposals for the constructive improvement of the hinge elements of the spindles. 
To achieve this aim it is necessary to perform the following tasks:

1. Create a mathematical model of a typical universal spindle hinge joint.

2. Determine the influence of liner parameters on the pressure in the contact zone.

\section{Research of existing solutions of the problem}

Among the main directions of solving the problem of reducing the unevenness of contact pressure in joints with sliding friction, a number of works have beenidentified.

So, in work [1], important studies of the nature of wear in the zone of contact of the sliding hinge of a universal spindle are presented. The sites of increased abrasive wear are detected and ways to create protective films with increased hardness are suggested. However, a more radical solution to the problem is considered by equalizing the pressure on the contact surface.

In [2], the pattern of wear of the spindle inserts by the method of artificial bases is determined. The obtained results allow to estimate the distribution of the acting forces on the contact surfaces of the hinges. The approach is modern, but the possibility of reducing the pressure in the contact zone is not considered.

In [3], the spindle with the original design of the ball joint is considered. With the growth of skew angles, there is a decrease in the quality of rolled metal and there are cases of breakdowns. To improve the reliability of the hinge, studies are carried out on a three-dimensional spatial model. Uneven operation of the balls in the gearing and their pinching are revealed, which hinders the use of progressive hinges on powerful mills.

In [4], the causes of the destruction of the spindle and work rolls are investigated using the finite element analysis method. It is revealed that the destruction begins with the breakdown of the share of the spindle head. This underlines the need for additional study of the nature of the loads in the hinge and the importance of increasing its reliability.

In [5], the evaluation of the structural and technological parameters of the spindle joint is made using the example of a hot sheet rolling mill. The lack of opera- tional reliability of the hinge is determined. However, the features of the hinge at different angles of skew are not considered.

In [6], a study of the stress-strain state of the rolling mill spindle is carried out. Safe operating modes and loads are determined depending on the spindle skew angle. However, not enough attention is paid to the nature of the distribution of loads in the hinge itself.

In [7], a new design of the universal spindle hinge is presented, in which a uniform distribution of contact pressures is achieved by changing the sectional area of the liners in length and width.

The authors of [8] using the example of experimental studies of the plate mill 5000 establish a significant excess of the dynamic moments of the drive of the rolls during the capture of the strip. The causes are identified and a control method is developed, which reduces the load on the spindle. However, this work does not take into account the negative impact of dynamic moments on the work of the hinge.

In [9], theoretical materials on the method of calculating universal spindles are considered. The outlined material allows to extend the detailed study of the problem of wear of the hinge liners with the current trends.

The information in [10] presents the versatile hinges of universal spindles of the leading Swiss manufacturing company TNCE GmbH, having high quality and durability. The introduction of these hinges in the Ukrainian states requires a special adjustment for rolls and drives, which significantly increases their cost and complicates maintenance.

Thus, the results of the analysis allow to conclude that there is a need to develop a mathematical model of the hinge joint to study the nature of the pressure distribution in the contact surfaces and the development of tools to improve the reliability of universal spindles.

\section{Methods of research}

Analytical research of loads in the hinge area is conducted to search for a rational design of the hinge spindles (Fig. 1). The hinge includes a liner 1, which is located in a special cylindrical groove of the spindle head 2, roller blade 3 . The blade and the liner segments are joined by axle.
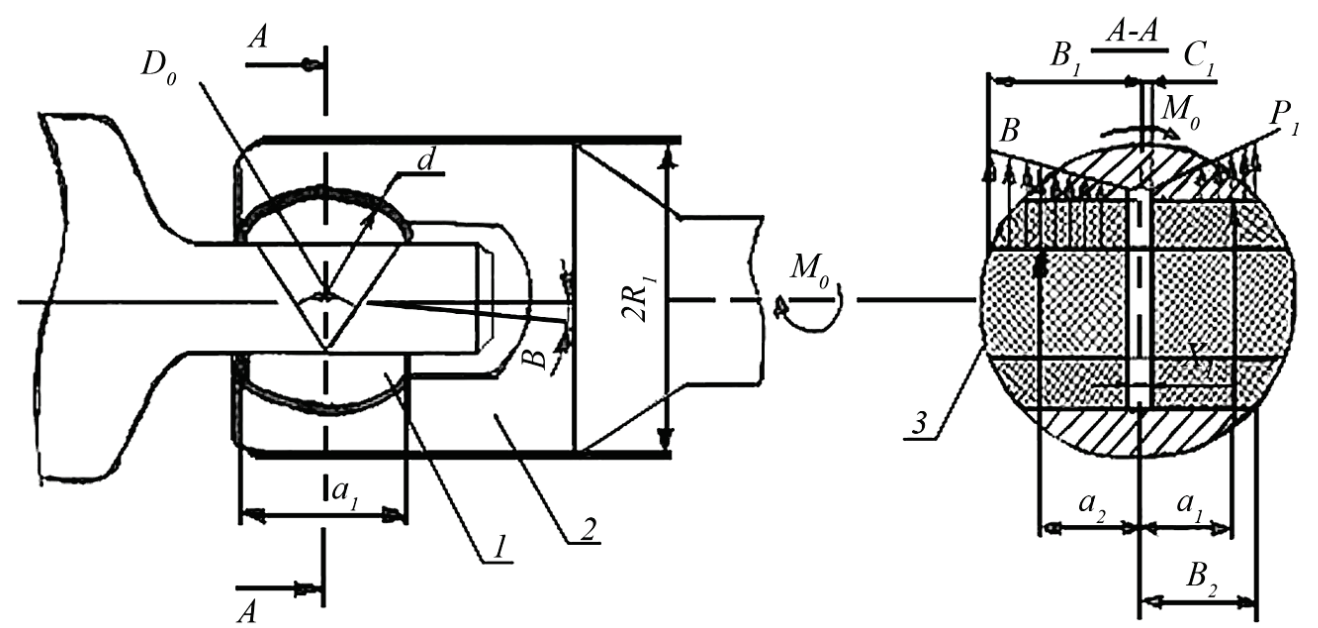

Fig. 1. Equipment and loads of a typical universal spindle hinge of a rolling mill: 1 - liner; 2 - special groove of the spindle head; 3 - roller blade 
In Fig. 1:

$D_{0}$ - hinge diameter;

$d$ - tolerance value of the fit tolerance;

$a_{1}$ - hinge length;

$a_{2}$ - distance of the averaged pressure on the liner from the central axis of the hinge;

$B$ - point where there is a maximum pressure value;

$2 R_{1}$ - diameter of the spindle head;

$M_{0}$ - torque on the spindle;

$B_{1}$ - length of half section of the contact surface of the liner;

$B_{2}$ - length of half section of the

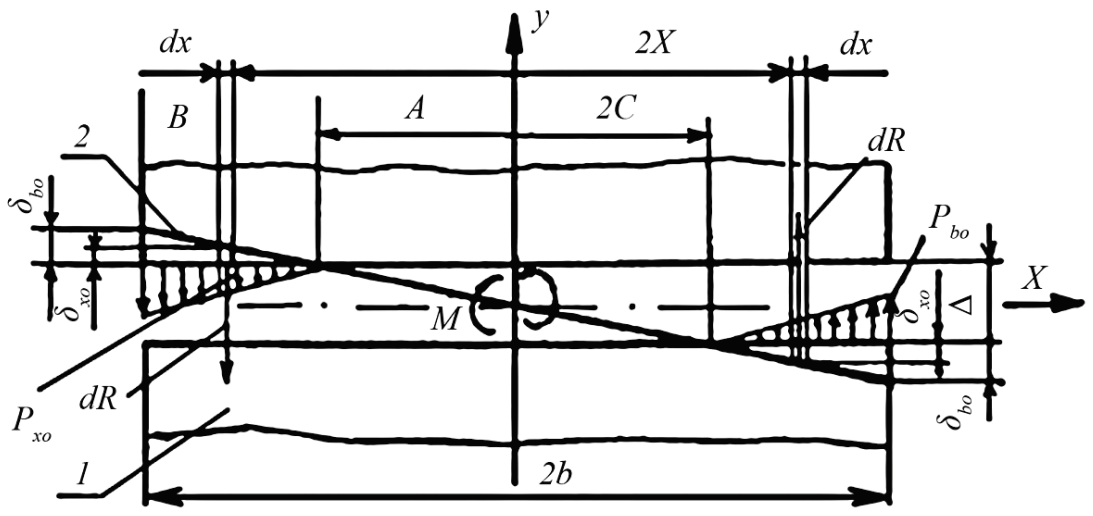
bearing surface of the liner;

$C_{1}$ - transverse size of half section of the spindle axis;

$P_{1}-$ plot of pressure distribution on the unloaded side of the liner;

$X_{1}$ - full size section of the hinge axis.

It is known that the main element that is replaced during repairs is liners, which are usually made of antifriction materials based on bronze and are more susceptible to wear. Analytical studies are conducted to determine the nature of the load on the liner segments and the distribution of pressure along the length. The hinge model consists of the following assumptions: the liner is compressed between absolutely rigid elements - the roller blade and the spindle head, where the liner segments are located (Fig. 2).

In Fig. 2:

$\delta_{x o}, \delta_{b o}$ - deformation of the liner in a randomly selected section and at the edges along the length of the hinge;

$2 x, d x$ - respectively, the distance to arbitrarily selected areas of the working surface of the contact of the blade and the hinge with extremely small dimensions;

$d R$ - pressure value in this area;

$P_{x o}, P_{b o}$ - respectively, the maximum pressure on section $x$ and the outer edge of the hinge segment;

$2 b$ - length of the contact surface of the hinge;

$M$ - torque of the universal spindle;

$2 c$ - length of the underformed area of the liner;

$\Delta$ - maximum mounting gap between the liner segments.

In order to simplify the model, the roller blade when transmitting torque from the spindle to the roller is reflected by a straight line 2 , and the distance between the liner segments is equal to the maximum mounting gap between them:

$$
\Delta=\left(2 \cdot 10^{-3}-0.55 \cdot 10^{-3}\right) \cdot D,
$$

where $D$ - hinge diameter, mm. According to Hooke's law and the accepted definitions of the model, a formula for the dependence of pressure at a point with $x, z$ coordinates on the working surface of the insert in length and width is obtained (Fig. 2, 3) [7]:

$$
P_{X Z}=\frac{E \cdot \Delta \cdot a \cdot(x-c)}{2 c \cdot[m \cdot a-z \cdot(m-n)]},
$$

where $c$ - half the length of the non-deformed zone of the liner segment; $m, n, a$ - dimensions of the insert section (Fig. 3); $E$ - elasticity modulus of the material of the liners.
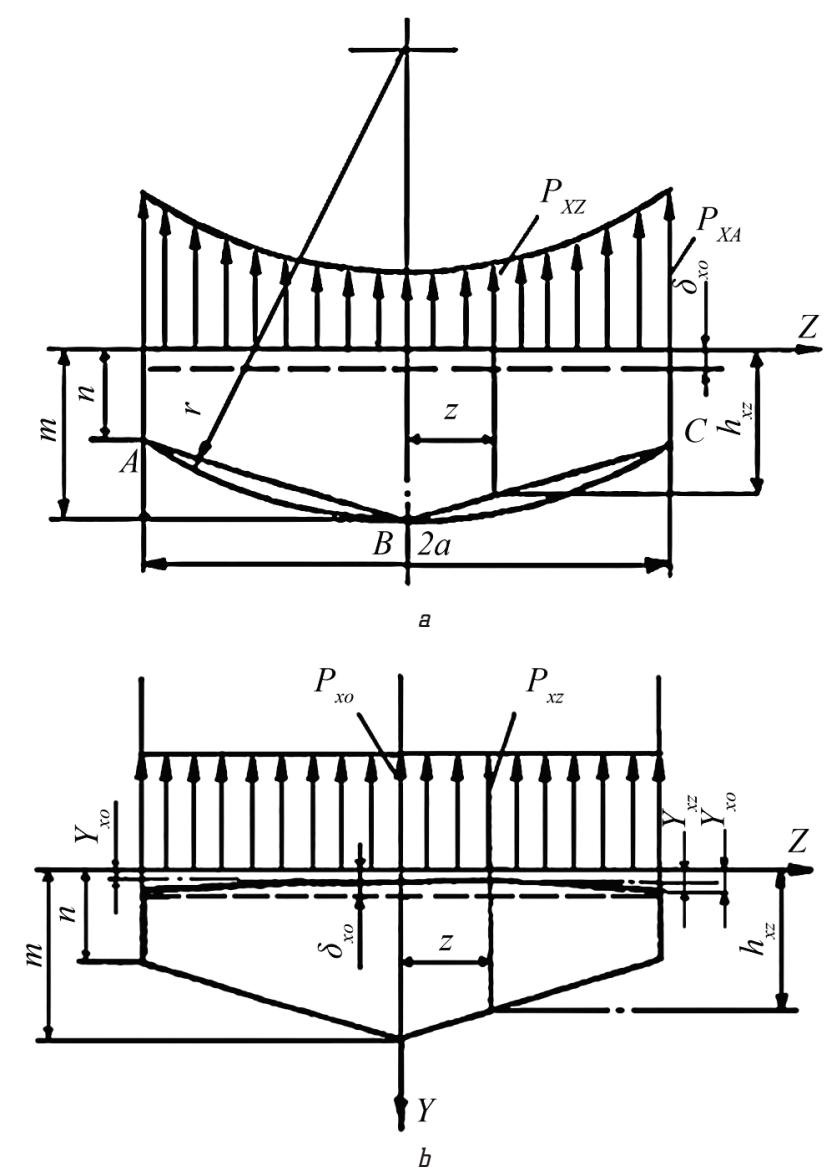

Fig. 3. Pressure distribution across the liner width: a - diagram of pressure on the contact surface of the standard design of the sliding joint; $b$ - pressure distribution in the proposed design of the hinge with bevels; $P_{X A}-$ maximum value of pressure on the contact surface; $r$ - radius of the bearing surface of the liner; $2 a$ - full liner width; $h_{x z}$ - height of the section of the insert at a distance $z$ from the central axis of the insert; $Y_{x o}$ - maximum amount of bevel to the side faces; $z$ - an arbitrary distance on the liner pressure plot

On the basis of a defined formula (1), the pressure values are calculated across the liner width and pressure diagrams are constructed that are non-linear with highpressure zones (corner zones, Fig. 3, $a$ ). This is confirmed by the nature of the contact loads of the created model (Fig. 2). A certain uneven pressure negatively affects the running-in. To reduce the uneven pressures, it is proposed to change the shape of the liner [8]. On a flat working surface, bevels are made with a slope to the ends of the 
liner in length and with a slope from the middle to the side faces in width. The magnitude of the slopes is determined by the dependence:

$$
Y_{B A}=\frac{\Delta(m-n) \cdot(b-c)}{2 m \cdot c-\Delta \cdot(b-c)},
$$

where $b$ - half liner length.

\section{Research results}

Experimental studies have shown that the presence of slopes and the next wear of the working surface within $(0.015-0.1) \cdot D$ can be achieved by equalizing the pressure across the width of the liner (Fig. $3, b$ ). The pressure in this case is determined as follows:

$$
P_{X Z}=\frac{\Delta \cdot(x-c) \cdot K}{4 a \cdot c}
$$

where $K$ - specific stiffness of the liner (stiffness coefficient of the liner of unit length).

To determine its value, the $A B C$ arc is replaced by two chords (Fig. $3, a, b$ ). In this case, $K$ will be equal to:

$$
K=2 E \int_{0}^{a} \frac{d z}{h_{X Z}}=\frac{2 E \cdot a \cdot \ln (m / n)}{m-n},
$$

where $d z / h_{x z}-$ thickness gradient of the liner segment.

In accordance with the laws of geometric modeling, the segment $r, n, m, a, b$ and half of the blade thickness $S$ are directly proportional to the radius $R_{o}$ of the liner segment (Fig. 3) and are determined by the formulas:

$$
\begin{aligned}
& r=K_{r} \cdot R_{h} ; \quad n=K_{n} \cdot R_{h} ; \quad m=K_{m} \cdot R_{h} ; \\
& a=K_{a} \cdot R_{h} ; \quad b=K_{b} \cdot R_{h} ; \quad S=K_{S} \cdot R_{h},
\end{aligned}
$$

where $K_{r}$ - proportionality coefficient of the bearing surface radius; $K_{n}$ - proportionality coefficient of the external liner height; $K_{m}$ - proportionality coefficient of the maximum liner thickness; $K_{a}$ - proportionality coefficient of half the width of the liner segment; $K_{b}$ - proportionality coefficient of half the blade length; $K_{s}$ - proportionality coefficient of half the blade thickness; $R_{h}$ - hinge radius.

The specific stiffness of the liner $K$ will be equal to:

$$
K=\frac{2 E \cdot K_{a}}{\left(K_{r}-\sqrt{K_{r}^{2}-K_{a}^{2}}\right)} \cdot \ln \frac{\left(K_{r}-K_{S}\right)}{\left(\sqrt{K_{r}^{2}-K_{a}^{2}}-K_{S}\right)}=K_{0} \cdot E,
$$

where $K_{0}$ - generalized coefficient of the specific stiffness of the liner.

From the above calculations it can be seen that by reducing the elastic modulus of the material of the liners, it is possible to achieve a significant decrease in pressure on their working surface. For standard hinges: $K_{r}=0.45 \ldots 0.46$; $K_{a}=0.30 \ldots 0.31 ; K_{s}=0.25 \ldots 0.26$ and $K_{0} \approx 5$.

To assess the accuracy of certain dependencies [9], field tests of liner elements $50 \mathrm{~mm}$ long are carried out. They are squeezed between two plates, the contact surfaces of which corresponded to the working surfaces of the roller and the blade. The deformation is performed on a hydraulic press with a force of $4 \mathrm{MN}$ and measured by three indicators. For the studied elements $(m=0.085 \mathrm{~m}$; $n=0.04 \mathrm{~m} ; 2 a=0.25 \mathrm{~m} ; E=1.05 \cdot 10^{5} \mathrm{MPa}$ ) with the calculated value $K=4.25 \cdot 10^{5} \mathrm{MPa}$, the average experimental value is $3.55 \cdot 10^{5} \mathrm{MPa}$. This discrepancy $(\approx 16 \%)$ is acceptable for engineering calculations, allows the use of certain dependencies for the qualitative assessment of the parameters of hinges.

\section{SWOT analysis of research results}

Strengths. The research results and the proposed improvement of the spindle allow for pressure equalization across the width of the hinge liner. Compared with the analogues [1,2], the service life of the hinge, the universal spindle and the rolling mill as a whole is increased.

Weaknesses. Somewhat increases the complexity of the design of the liner due to the manufacture of bevels on a flat surface with a slope to the ends along the length of the liner and from its middle to the side faces [9]. The time of liner manufacture increases.

Opportunities. It is planned to develop a more advanced mathematical model of the hinge for the study of composite non-metallic liner materials with less stiffness and higher anti-friction properties.

When introducing the invention and the results of the study, non-production stops of the rolling process are reduced due to the increased wear of conventional liners.

Threats. There are developments of damping inserts for universal spindles of rolling mills, which have a high cost and are included in the full set of state [10], therefore, the purchase of such states is economically unprofitable.

\section{Conclusions}

1. A mathematical model of loads of a typical universal hinge joint of the spindle with a possible gap $\Delta=$ $=\left(2 \cdot 10^{-3}-0.55 \cdot 10^{-3}\right) \cdot D \mathrm{~mm}$ is developed. This model is designed to determine the nature of the action of loads on the contact surface in the hinge.

2. The influence of the parameters of the liners on the pressure in the contact zone is determined; it has a non-linear parabolic character. The pressure on the contact surface ranges from $11.55-42.05 \mathrm{MPa}$. The possibility of uniform pressure distribution along the length and width of the segments of the liners is shown. With the following parameters: $x=6 \mathrm{~cm} ; c=4 \mathrm{~cm} ; a=18 \mathrm{~cm} ; K=1.05 \cdot 10^{5} \mathrm{MPa}$, the pressure leveled off and decreased to a value of $35.7-33.64 \mathrm{MPa}$, which is $16-20 \%$ lower than the maximum pressure value of a typical hinge. The calculated specific stiffness of the liner $\left(4.25 \cdot 10^{5} \mathrm{MPa}\right)$, which is $16 \%$ different from the experimental value, is determined.

\section{References}

1. Kravchenko V. M., Sidorov V. A., Butsukin V. V. Iznos lopastey universal'nogo shpindelya prokatnogo stana // Visnik PDTU. 2012. Issue 24. P. 262-265.

2. Sidorov V. A., Nizhnik N. V. Zakonomernost' iznosa vkladyshey universal'nogo shpindelya prokatnykh stanov // Metallurgicheskaya i gornorudnaya promyshlennost'. 2005. Issue 33. P. 94-96.

3. Plakhtin V. D., Ivochkin M. Yu., Dmitryuk S. O. Issledovanie sharnira sharovogo shpindelya stana 250 // SAPR i grafika. 2011. Issue 4. P. 32-35. 
4. Fracture Failure Analysis of Main Drive Spindle and Working Roll in 1780 Mill R2 Rougher Mill / Lou S. et. al. // Jixie Qiandu. 2014. Vol. 36, Issue 5. P. 809-812.

5. Buzyuma R. V., Kharitonenko A. A. Otsenka konstruktivnykh i tekhnologicheskikh parametrov pri modernizatsii shpindel'nogo soedineniya privoda kleti tonkolistovogo stana goryachey prokatki // Povysheniya nadezhnosti metallurgicheskogo proizvodstva. Lipetsk: LiGTU, 2018. P. 134-137.

6. Ivochkin M. Yu., Gurevich Yu. A., Dmitryuk S. O. Issledovanie napryazhenno-deformirovannogo sostoyaniya elementov valkov prokatnykh stanov // Izvestiya Moskovskogo politekhnicheskogo universiteta. 2014. Vol. 5, Issue 4 (22). P. 13-16.

7. Vkladysh sharnira universal'nogo shpindelya: A.C. 1103914 SSSR. MPK V 21 b 35/14 / Potapenkov A. P., Kasperovich E. B., Tkachenko A. A. No. 3511064/22; declareted: 17.11.80; published: 23.07.84. Bul. No, 27.

8. Shubin A. G., Loginov B. M., Gasiyarov V. R. Obosnovanie sposobov ogranicheniya dinamicheskikh nagruzok elektromekhanicheskikh sistem kleti prokatnogo stana // Elektrotekhnicheskie sistemy i kompleksy. 2011. Issue 3 (40). P. 14-25.

9. Sovershenstvovanie konstruktsii i metodiki rascheta universal'nykh shpindeley prokatnykh stanov / Potapenkov A. P. et. al. // Naukovi pratsi ZDIA. 2014. Issue 1. P. 158-163.
10. Proizvodstvenno-inzhiniringovaya kampaniya ENCE GmbH. URL: http://ence.ch/ru/

Tarasov Vyacheslav, PhD, Associate Professor, Center for Continuing Education, Zaporizhzhia State Engineering Academy, Ukraine, ORCID: http://orcid.org/0000-0002-4404-3454,e-mail: tvk1937@ukr.net

Rumyantsev Vladislav, PhD, Associate Professor, Department of Metallurgy, Zaporizhzhia State Engineering Academy, Ukraine, ORCID: http://orcid.org/0000-0003-0186-4823,e-mail: ruvlad1164@gmail.com

Mosejko Yuri, PhD, Associate Professor, Department of Metallurgy, Zaporizhzhia State Engineering Academy, Ukraine, ORCID: http:// orcid.org/0000-0001-7342-6772

Potapenkov Alexander, Doctor of Technical Sciences, Professor, Department of Technological Machines and Equipment, Norilsk State Industrial Institute, Russia, ORCID: http://orcid.org/0000-00020751-531X, e-mail: tok1937@ukr.net

\section{Nazarenko I., Dedov 0., Svidersky A., Oryshchenko 5.}

\section{EXPERIMENTAL STUDIES OF FORMING DESIGN AT DYNAMIC LOAD}

Об’єктом досліджень є процес руху формоутворюючої конструкції вібраційної установки із просторовими коливаннями. Основним недоліком подібних вібросистем є відсутність даних про взаємовплив машин і середовищ. Розроблена та виготовлена експериментальна вібраційна установка. Установка обладнана двома асиметрично встановленими вібрачійними збуджувачами коливань, які прикріплені безпосередньо до формоутворюючої поверхні. Запропоновано нову методику вимірювання руху формоутворюючої конструкції із розташуванням датчиків в зонах динамічного навантаження. В основу їхього розташування покладено передумову визначення контактних сил взаємодї підсистем між собою. А також оцінку співвідношення часу дї та часу розповсюдження хвиль. Такий підхід є новим, оскільки враховує реальні співвідношення динамічних параметрів машини і середовища між собою і ступінь взаємовпливу. В ході дослідження використовувалися записи безперервної фіксацї розподілення активних коливань формоутворюючої поверхні. Отримано принципово новий результат, який полягає в тому, що перехідний процес передбачено враховувати при визначені параметрів та місць розташування вібраторів. Завдяки цьому реалізуються форми власних коливань системи з більшими за значенням амплітудами коливань та відповідно нижчою частотою. У порівнянні з аналогічними відомими конструкціями віброустановок ие дозволяє значно зменшити енергоємність приводів вібраційної машини. Застосування пневматичних збудників в реальних заводських умовах знижує рівень шуму та прискорює швидкодію прощесу ущільнення бетонної суміші. Розроблені практичні рекомендачї для раціонального конструктивного оформлення перерізів формоутворюючої конструкиії. Визначені технологічні параметри коливань з новими значеннями вихідних числових значень амплітудно-частотного режиму збудника коливань. Для конструювання подібних формоутворюючих конструкцій визначені місия установки вібраторів. Отримані результати можуть бути використані у суміжних процесах, наприклад, в горнорудній промисловості, як активні поверхні для транспортування руди, для переміщення суспензій і розчинів в хімічній промисловості.

ключові слова: експериментальна модель, формоутворююча конструкція, просторове навантаження, напружено-деформований стан.

\section{Introduction}

At the present stage of development of the construction industry there is an urgent problem of introducing such technologies and machines, which make it possible to ensure high quality of the finished product, a significant reduction in energy costs and increased productivity. Energy saving is an urgent task of research and development. Vibration machines and processes occupy an important place in the construction industry. With the help of vibration, 